\title{
STUDI KOMPARATIF PENDAPTAN DAN KESEMPATAN KERJA PADA USAHTANI KEDELAI DENGAN SISTEM TANAM SEBAR DAN TUGAL DI KECAMATAN ALAS KABUPATEN SUMBAWA
}

\section{COMPARATIVE STUDY OF FARMING INCOME AND LABOR OPPORTUNITIES ON SPREAD CROPPING SYSTEM AND DIGGING STICK SOYBEAN FARMING AT ALAS DISTRICT IN SUMBAWA REGENCY}

\author{
Vita Anggi Tapisa, Bambang Dipokusumo, Hirwan Hamidi \\ Program Studi Agribisnis Fakultas Pertanian UNRAM
}

\begin{abstract}
ABSTRAK
Penelitian ini bertujuan untuk: (1) mengkaji perbandingan struktur pembiayaan usahatani kedelai dengan sistem tanam sebar dan sistem tanam tugal. (2) mengkaji perbandingan produksi usahatani kedelai dengan sistem tanam sebar dan sistem tanam tugal, (3) mengkaji perbandingan pendapatan usahatani kedelai sistem tanam sebar dan sistem tanam tugal, (4) mengkaji kesempatan kerja yang tersedia pada usahatani kedelai dengan sistem tanam tanam sebar dan sistem tanam tugal. Penelitian ini menggunakan metode deskriptif dengan tekhnik survei. Data yang diperoleh dianalisis menggunakan uji $\mathrm{t}$ data tidak berpasangan. Hasil penelitian menunjukkan bahwa: (1) Biaya produksi pada usahatani kedelai sistem sebar lebih kecil dibandingkan usahatani kedelai sistem tugal dengan nilai masing-masing secara berurutan sebesar Rp 5.741.324/ha dan Rp 7.205.809/ ha, dengan persentase biaya variabel masing-masing sebesar $97,47 \%$ dan $97,68 \%$ dan sisanya $2,53 \%$ dan 2,32\% pada biaya tetap. (2) Produksi pada usahatani kedelai sistem sebar lebih kecil dibandingkan usahatani kedelai sistem tugal setelah diuji dengan uji-t dengan taraf nyata $0,5 \%$ dengan nilai masing-masing secara berurutan sebesar $1.301,42 \mathrm{~kg} / \mathrm{ha}$ sebesar 1.787,04 kg/ha. (3) Pendapatan pada usahatani kedelai sistem sebar lebih kecil dibandingkan usahatani kedelai sistem tugal dengan nilai masing-masing secara berurutan sebesar Rp 1.806.935,65/ha; Rp 3.159.007,17/ha. (4) Kesempatan kerja pada usahatani kedelai sistem sebar dan sitem tugal sama dengan nilai masingmasing secara berurutan sebesar 53,47 HKO/ha dan 61,06 HKO/ha, dengan kesempatan kerja paling banyak berda pada jenis kegiatan penanaman dan pemanenan yang masing-masing sebesar 8,71 $\mathrm{HKO} / \mathrm{ha}$ dan 12,82 $\mathrm{HKO} /$ ha pada sistem sebar sedangkan 12,59 $\mathrm{HKO} /$ ha dan 12,82 $\mathrm{HKO} /$ ha pada sistem tugal. (1) Disarankan kepada pemerintah untuk melakukan penyuluhan kepada petani untuk menggunakan sistem tanam tugal dalam usahatani kedelai. (2) Disarankan kepada petani untuk mengoptimalkan penggunaan input seperti pupuk sesuai dengan yang direkomendasikan. (3) Disarankan kepada petani untuk menggunakan teknologi pemupukan menggunakan sistem pembenaman di antara baris tanaman.
\end{abstract}




\begin{abstract}
This study aims to: (1) To assess the comparison of the financing structure of soybean farming with spread cropping system and digging stick. (2) To examine the comparison of soybean farming production with spread cropping system and digging stick. (3) To examine the comparison of soybean farming income of spread cropping system and digging stick. (4) To assess available employment opportunities in soybean farming with spread cropping system and digging stick. This study uses descriptive methods with survey techniques. The data obtained were analyzed using unpaired data t test. The results showed that: (1) Production costs on soybean farming systems were smaller than those of digging stick soybean farming with their

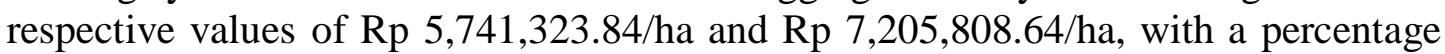
variable costs were $97.47 \%$ and $97.68 \%$ and the remaining $2.53 \%$ and $2.32 \%$ at fixed costs. (2) Production on soybean farming system is smaller than tugal soybean farming after being tested by t-test with a real level of $0.5 \%$ with respective values of $1,301.42 \mathrm{~kg} / \mathrm{ha}$ of $1,787.04 \mathrm{~kg} / \mathrm{ha}$. (3) Revenue on soybean farming system spreads smaller than digging stick system soybean farming with their respective values of Rp. 1,806,935.65/ha for Rp. 3,159,007.17/ha. (4) Job opportunities in the soybean farming system spread and digging stick system are equal to respectively value of $53.47 \mathrm{HKO} / \mathrm{ha}$ and $61.06 \mathrm{HKO} / \mathrm{ha}$, with the most employment opportunities in each type of planting and harvesting activities -same at $8.71, \mathrm{HKO} / \mathrm{ha}$ and 12.82 $\mathrm{HKO} /$ ha on spread systems while $12.59 \mathrm{HKO} / \mathrm{ha}$ and $12.82 \mathrm{HKO} / \mathrm{ha}$ on digging stick systems. Suggestions that can be given (1) It is recommended to the government to conduct counseling to farmers to use digging stick planting systems in soybean farming. (2) It is recommended to farmers to optimize the use of inputs such as fertilizers as recommended. (3) It is recommended to farmers to use fertilization technology using a seeding system between rows of plants.
\end{abstract}

\title{
PENDAHULUAN
}

Swasembada pangan adalah keadaan dimana suatu negara dapat memenuhi tingkat permintaan akan suatu bahan pangan sendiri tanpa perlu mengiimpor dari pihak luar. Dimana untuk saat ini indonesia masih mengimpor beberapa komoditas pangan.

Untuk mencapai swasembada pangan, pemerintah telah melakukan beberapa program dan salah satu program tersebut adalah program Upsus Pajale (Upaya khusus Padi, jagung, dan kedelai). Pada kegiatan program upsus pajale, segala strategi dilakukan untuk meningkatkan luas tanam dan produktivitas di daerahdaerah sentra produksi pangan melalui kegiatan rehabilitasi jaringan irigasi tersier dan kegiatan pendukung lainnya.

Kedelai (Gline max) dikenal sebagai komoditi tanaman pangan yang banyak dikonsumsi rakyat Indonesia karena selain nerupakan sumber protein nabati, kedelai juga di kenal murah dan terjangkau oleh sebagian besar masyarakat Indonesia (Amang, 1998).

Kebutuhan kedelai di dalam negeri tiap tahun cenderung terus meningkat, sedangkan persediaan produksi belum mampu mengimbangi permintaan. Berdasarkan perkiraan Departemen Pertanian tentang proyeksi produksi dan 
penyediaan bahan pangan harus ditingkatkan guna memenuhi kebutuhan penduduk yang cendrung meningkat tiap tahun (Rukmana dan Yuyun, 1996).

Sistem tanam merupakan salah satu komponen kunci dalam pengembangan suatu tekhnologi produksi sebagai upaya untuk meningkatkan produksi pertanian. Maka dari itu pemerintah menganjurkan petani untuk menggunakan sistem tanam tugal yang dapat meningkatkan jumlah produksi, sedangkan sistem tanam yang berkembang di masyarakat adalah sistem tanam sebar. Untuk mengkaji sistem tanam sebar dan tugal peneliti ingin menganalisis keuntungan dan kerugian kedua sistem tersebut, dalam segi proses produksi, biaya, kesempatan kerja, pendapatan, dan kendala-kendala yang dihadapi petani dalam menggunakan kedua sistem tanam tersebut. Oleh karena itu penelitian ini selain mengungkap tentang perbandingan produksi dan pendapatan juga akan dianalisis tentang kesempatan kerja. Penelitian serupa juga belum pernah dilakukan di Kabupaten Sumbawa khususnya Kecamatan Alas, maka peneliti ingin melakukan penelitian yang berjudul "Studi Komparatif Pendapatan dan Kesempatan Kerja Usahatani Kedelai dengan Sistem Sebar dan Tugal di Kecamatan Alas Kabupaten Sumbawa". Adapun tujuan dari penelitian ini adalah (1) Untuk mengkaji perbandingan struktur pembiayaan usahatani kedelai dengan sistem tanam sebar dan sistem tanam tugal di Kecamatan Alas Kabupaten Sumbawa. (2) Untuk mengkaji perbandingan produksi usahatani kedelai dengan sistem tanam sebar dan sistem tanam tugal di Kecamatan Alas Kabupaten Sumbawa. (3) Untuk mengkaji perbandingan pendapatan usahatani kedelai sistem tanam sebar dan sistem tana tugal di Kecamatan Alas Kabupaten Sumbawa. (4) Untuk mengkaji kesempatan kerja yang tersedia pada usahatani kedelai dengan sistem tanam tanam sebar dan sistem tanam tugal di Kecamatan Alas Kabupaten Sumbawa.

\section{METODOLOGI PENELITIAN}

Penelitian ini menggunakan metode deskriptif, yaitu metode yang mengarahkan pada pemecahan masalah yang ada pada waktu sekarang dengan cara mengumpulkan kemudian menyusun dan menginterpretasikan data, menetapkan hubungan dan kebutuhan masing-masing variabel yang di teliti dan selanjutnya dianalisa dan menarik kesimpulan (Nasir, 1988). Pengumpulan data dilakukan dengan mewawancarai responden dengan berpedoman pada daftar pertanyaan yang telah di persiapkan (Surakhmad, 1990).

\section{Penentuan Daerah Sampel}

Penelitian ini dilakukan di Kecamatan Alas, dengan sebaran tanam pada Desa Juranalas, Desa Kalimango, Desa Dalam, dan Desa Luar. Dari desa-desa tersebut di pilih dua desa untuk penentuan lokasi penelitian yang dilakukan secara purposive sampling dengan pertimbangan lokasi penelitian merupakan daerah yang menghasilkan komoditi kedelai dengan sistem sebar dan tugal yang paling banyak yaitu Desa Juranalas dan Desa Luar.

\section{Penentuan Responden}

Penentuan jumlah petani sebagai responden ditetapkan menggunakan quota sampling yang dimana akan ditetapkan responden sebanyak 30 petani, 20 responden 
dari petani yang menanam Kedelai dengan sistem sebar dan 10 responden dari petani yang menanam Kedelai dengan sistem tugal. Dalam melakukan penelitian peneliti akan menggunakan teknik random sampling, random sampling adalah teknik pengambilan sampel di mana semua individu dalam populasi baik secara sendirisendiri atau bersama-sama diberi kesempatan yang sama untuk dipilih menjadi anggota sampel (Narbuko dan Achmadi, 2007).

\section{Analisis Data}

Data yang diperoleh dari penelitian dianalisis dengan cara sebagai berikut:

1. Untuk mengetahui besarnya pendapatan usahatani kedelai dianalisis dengan menggunakan analisis biaya dan pendapatan, $\mathrm{I}=\mathrm{TR}-\mathrm{TC}$; dimana $\mathrm{I}=$ Pendapatan Usahatani, $\mathrm{TR}=$ Total Penerimaan, $\mathrm{TC}=$ Total Biaya Produksi.

2. Kesempatan kerja adalah keadaan yang menggambarkan ketersediaan lapangan kerja untuk para pencari kerja atau petani atau buruh tani, dapat dirumuskan sebagai berikut :

$$
\begin{aligned}
& \text { Kesempatan Kerja = } \frac{\mathrm{t} \times \mathrm{h} \times \mathrm{j}}{7} \\
& \text { Keterangan } \\
& \begin{aligned}
& \mathrm{t} \quad \text { = Jumlah tenaga kerja } \\
& \mathrm{h}=\text { Jumlah hari kerja } \\
& \mathrm{j}=\text { Jumlah jam kerja } \\
& 7=\text { Standar kerja per hari }
\end{aligned}
\end{aligned}
$$

3. Perbandingan, untuk membandingkan biaya, produksi, kesempatan kerja dan pendapatan usahatani kedelai dengan sistem sebar dan tugal, digunakan t-test.

\section{HASIL DAN PEMBAHASAN}

\section{a. Umur Responden}

Umur petani responden pada sistem sebar lebih banyak pada kisaran umur di atas 50 tahun dengan persentase $65 \%$ dan sisanya $35 \%$ berumur kisaran $35-50$ tahun, sedangkan petani responden pada sistem tugal berada pada kisaran 35-50 tahun $(50 \%)$ dan di atas 50 tahun dengan persentase $50 \%$. Artinya sebagian besar petani kedelai berumur di atas 50 tahun yang berarti petani responden berada dalam umur produktif.

\section{b. Tingkat Pendidikan Responden}

Petani responden usahatani kedelai sistem sebar tingkat pendidikannya paling banyak tamat SD, tamat SMP, dan tamat SMA dengan masing-masing sebanyak 6 orang dan persentasenya masing-masing $30 \%$, sedangkan pada petani sistem tugal tingkat pendidikan paling banyak tamat SD dan tamat SMP dengan masing-masing sebanyak 4 orang dengan masing-masing persentasenya $40 \%$, maka dapat diketahui bahwa kualitas pendidikan responden petani responden relatif rendah. 


\section{c. Jumlah Anggota Keluarga}

Jumlah anggota keluarga petani responden sistem sebar dan tugal paling banyak berada pada lebih dari 4 jumlah anggota keluarga, pada sistem sebar sebanyak 14 orang dengan persentase sebesar $70 \%$ dan pada sistem tugal sebanyak 7 orang dengan persentase juga 70\%. Dengan anggota keluarga lebih dari 4 orang maka tergolong keluarga menengah.

\section{d. Pengalaman Berusahatani}

Pengalaman berusahatani mempengaruhi petani dalam mengelola usahanya terutama untuk mengambil keputusan tepat demi mencapai hasil yang optimal. pengalaman berusahatani petani responden sistem sebar dan tugal sebagian besar bearada pada kisaran 20-30 tahun dengan jumlah petani sistem sebar sebanyak 11 orang dengan persentase $55 \%$ dan petani sistem tugal sebayak 7 oarang dengan persentase $70 \%$. Dengan demikian pengalaman petani responden cukup dalam mengelola usahataninya.

\section{e. Luas Lahan Garapan}

Luas lahan garapan merupakan modal utama yang dimiliki dan besar kaitannya dengan pendapatan yang diperoleh oleh petani. Luas lahan garapan petani responden dengan sistem sebar lebih banyak pada kisaran 0,50-1,00 ha dengan jumlah petani sebanyak 9 orang dengan persentase $45 \%$, sedangkan luas lahan garapan petani sistem tugal lebih banyak pada kisaran kurang dari 0,50 ha dengan jumlah petani sebanyak 5 orang dengan jumlah persentase 50\%. Luas lahan garapan akan mempengaruhi jumlah produksi, dan jumlah produksi akan mempempengaruhi pendapatan dan biaya produksi.

\section{Penggunaan Input dan Biaya Usahatani Kedelai dengan Sistem Sebar dan Tugal}

\section{a. Biaya Produksi}

Biaya produksi petani responden pada usahatani kedelai sistem sebar dan tugal masing-masing sebesar Rp 5.741.323,84/ha dan Rp 7.205.808,64/ha. Hal ini terjadi karena pada biaya variabel tenaga kerja pada usahatani kedelai dengan sistem sebar lebih kecil di banding usahatani dengan sistem tugal yang masing-masing biaya sebesar Rp 3.062.104,43/ha dan Rp 3.637.037,04/ha. Pada biaya variabel lain juga terjadi perbedaan yang cukup jauh dengan biaya sistem sebar sebesar Rp 1.010.284,81/ha dan biaya sistem tugal sebesar Rp 1.728.888,89/ha.

\section{b. Biaya Sarana Produksi}

Biaya saprodi sistem sebar sebesar Rp 1.523.449,37/ha dan sistem tugal sebesar Rp 1.672.907,41/ha. Biaya benih pada sistem sebar senilai Rp 620.253/ha (40,71\%) dan sistem tugal senilai Rp 460.741,67/ha (27,54\%), perbedaan biaya ini terjadi karena penggunaan benih pada sistem sebar $(60,76 \mathrm{~kg} / \mathrm{ha})$ lebih banyak dibanding sistem tugal $(42 \mathrm{~kg} / \mathrm{ha}$ ) ini terjadi karena benih kedelai pada usahatani kedelai sistem sebar tidak efesien sehingga biaya benih lebih banyak. Benih yang digunakan petani responden adalah benih varietas Wilis dan Anjasmoro dengan

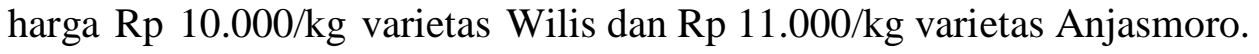


Penggunaan pupuk pada usahatani kedelai sistem sebar dan tugal tidak jauh berbeda yakni Rp 359.050,63/ha (23,56\%) dan Rp 319.388,89/ha (19,10\%). Sedangkan biaya herbisida pada kedua sistem terlihat perbedaan pada herbisida jenis roundup, perbedaan ini terjadi karena penggunaan roundup pada sistem tugal $(8,70)$ lebih banyak sehingga biaya pada sistem tugal lebih besar dibandingkan sistem sebar $(4,75)$ dengan biaya masing-masing sebesar $\mathrm{Rp} 739.814,81 / \mathrm{ha}(44,22 \%)$ dan Rp 403.481,01/ha (26,49\%), sedangkan penggunaan herbisida jenis rumpas pada sistem sebar dan tugal hampir sama dengan biaya sebesar Rp 140.664,56/ha $(9,23 \%)$ dan Rp 174,352,96/ha (10,42\%).

\section{c. Biaya Tenaga Kerja}

Rata-rata biaya tenaga kerja yang dikeluarkan petani responden yang menggunakan sistem sebar sejumlah Rp 3.062.104,43/ha sedangkan biaya tenaga kerja petani responden sistem tugal lebih banyak sebesar Rp 3.603.708/ha. Biaya tenaga kerja dalam keluarga pada sistem sebar dan tugal senilai Rp 1.260.680,38/ha $(42,46 \%)$ dan Rp 1.606.481,48/ha (44,10\%), sedangkan biaya tenga kerja luar keluarga pada sistem sebar sebesar Rp 1.801.424,05/ha (57,54\%) dan biaya tenaga kerja luar keluarga pada sistem tugal sebesar Rp 3.637.037,04/ha (55,9\%).

\section{d. Biaya Variabel Lain}

Biaya variabel pada sistem sebar lebih kecil dibandingkan sistem tugal yakni sebesar Rp 1.010.284,81/ha dan Rp 1.728.888,89/ha, perbedaan biaya ini disebabkan karena hasil produksi usahatani kedelai sistem tugal lebih banyak dibandingkan usahatani kedelai sistem sebar dan adanya perbedaan biaya yang cukup jauh pada biaya Iuran air yang disebabkan karena responden sistem sebar lebih banyak berada di Desa Juranalas yang pengairan irigasinya masih mencukupi petani sehingga petani hanya membayar iuran air sedangkan responden pada usahatani kedelai system tugal lebih banyak berasal dari Desa Luar yang ketersediaan pengairan irigasinya tidak mencukupi sehingga petani menaikan air menggunakan pompa yang biayanya cukup tinggi.Biaya tetap yang dikeluarkan usahatani sistem sebar dan tugal tidak terlalu berbeda yakni masing-masing sebesar Rp 145.485,23/ha dan Rp 166.975,31/ha.

\section{Produksi, Penerimaan, dan Pendapatan Usahatani Kedelai Sistem Sebar dan Tugal}

Tabel 1. Rata-rata Produksi, Penerimaan, Biaya Produksi, dan Pendapatan, Usahatani Kedelai dengan Sistem Sebar dan Tugal di Kecamatan Alas Kabupaten Sumbawa Tahun 2018

\begin{tabular}{|c|l|c|c|}
\hline \multirow{2}{*}{ No } & \multicolumn{1}{|c|}{ Uraian } & \multicolumn{2}{|c|}{ Sistem Usahatani } \\
\cline { 3 - 4 } & & Sistem Sebar & Sistem Tugal \\
\hline 1 & Produksi $(\mathrm{Kg})$ & $1.301,42$ & $1.787,04$ \\
\hline 2 & Penerimaan $(\mathrm{Rp})$ & $7.548 .259,49$ & $10.364 .814,81$ \\
\hline 3 & Biaya Produksi $(\mathrm{Rp})$ & $5.741 .321,84$ & $7.205 .808,64$ \\
\hline 4 & Pendapatan $(\mathrm{Rp})$ & $1.806 .935,65$ & $3.159 .006,17$ \\
\hline
\end{tabular}

Sumber : Data primer diolah, Tahun 2019 
Rata-rata produksi kedelai dengan sistem sebar lebih rendah dibandingkan sistem tugal yang masing-masing sebesar $1.301,42 \mathrm{~kg} / \mathrm{ha}$ dan $1787,04 \mathrm{~kg} / \mathrm{ha}$ dengan penerimaan masing-masing sebesar $\mathrm{Rp} 7.548 .259,49 / \mathrm{ha}$ dan $\mathrm{Rp} 10.364 .814,81 / \mathrm{ha}$. Adapun rata-rata biaya produksi pada usahatani kedelai sistem sebar dan sistem tugal masing-masing sebesar Rp 5.741.321,84/ha dan Rp 7.205.808,64/ha. Rata-rata pendapatan usahatani kedelai sistem sebar dan sistem tugal masing-masing $\mathrm{Rp}$ 1.806.935,65/ha dan Rp 3159006,17/ha. Pendapatan usahatani sistem tugal lebih tinggi dibandingkan sistem sebar ini disebabkan karena produksi kedelai dengan sistem tugal lebih tinggi tetapi biaya produksi yang dikeluarkan pada sistem tugal juga lebih tinggi ini disebabkan karena penggunaan tenaga kerja pada sistem tugal lebih banyak, petani yang memiliki modal lebih banyak biasanya menggunakan sistem tugal pada usahatani kedelainya, sedangkan petani yang memiliki modal relative lebih rendah biasanya menggunakan sistem sebar.

\section{Kesempatan Kerja}

Tabel 2. Kesempatan kerja pada usahtani kedelai dengan sistem sebar dan tugal di Kecamatan Alas Kabupaten Sumbawa, 2018.

\begin{tabular}{|l|r|r|r|r|r|r|r|r|}
\hline \multirow{2}{*}{$\begin{array}{l}\text { Jenis Kegiatan } \\
\text { Usahatani }\end{array}$} & \multicolumn{7}{|c|}{ Sesempatan } \\
\cline { 2 - 10 } & $\begin{array}{c}\text { DK } \\
\text { (HKO) }\end{array}$ & $\begin{array}{c}\text { LK } \\
\text { (HKO) }\end{array}$ & $\begin{array}{c}\text { Total } \\
\text { (HKO) }\end{array}$ & $\%$ & $\begin{array}{c}\text { DK } \\
(\text { HKO) }\end{array}$ & $\begin{array}{c}\text { LK } \\
(\text { HKO }\end{array}$ & $\begin{array}{l}\text { Total } \\
(\text { HKO })\end{array}$ & $\%$ \\
\hline $\begin{array}{l}\text { Penyiapan } \\
\text { Lahan }\end{array}$ & 1,55 & 0,08 & 1,63 & 3,05 & 1,61 & 0,00 & 1,61 & 2,64 \\
\hline Penanaman & 2,06 & 6,65 & 8,71 & 16,30 & 2,78 & 12,59 & 15,37 & 25,18 \\
\hline Pemupukan & 5,32 & 2,85 & 8,17 & 15,28 & 6,98 & 2,22 & 9,20 & 15,07 \\
\hline Penyemprotan & 4,11 & 3,80 & 7,91 & 14,80 & 4,34 & 2,59 & 6,93 & 11,35 \\
\hline Pengairan & 6,17 & 0,47 & 6,64 & 12,41 & 5,95 & 2,54 & 8,49 & 13,90 \\
\hline Pemanenan & 2,14 & 10,68 & 12,82 & 23,98 & 2,59 & 8,33 & 10,92 & 17,89 \\
\hline Perontokan & 2,06 & 5,54 & 7,60 & 14,21 & 2,59 & 5,93 & 8,52 & 13,93 \\
\hline \multicolumn{1}{|c|}{ Tota } & 23,42 & 30,06 & 53,47 & 100 & 26,85 & 34,21 & 61,06 & 100 \\
\hline
\end{tabular}

Sumber : Data Primer diolah, 2019

Dari tabel 2, dapat di lihat bahwa kesempatan kerja pada kegiatan usahatani kedelai sistem sebar dan sistem tugal masing-masing secara berurutan yaitu 53,42 HKO/ha dan 61,06 HKO/ha. Kesempatan kerja pada kegiatan penyiapan lahan pada sistem sebar sebesar 31,63 HKO dengan persentase 3,05\%, sedangkan pada sistem tugal sebesar 1,61 HKO dengan persentas 2,64\%. Pada kegiatan penanaman kesempatan kerja pada sistem sebar dan tugal masing-masing sebesar 8,17 HKO dengan persentase $15,28 \%$ dan $15,37 \mathrm{HKO}$ dengan persntase $25,18 \%$. Pada kegiatan pemupukan kesempatan kerja pada sistem sebar dan tugal masing- masing sebesar 8,17 HKO dengan persentase $15,28 \%$ dan 9,20 HKO dengan persentase $15,07 \%$. Kesempatan kerja pada kegiatan penyemprotan pada sistem sebar sebesar 7,91 HKO dengan persentase 14,80\%, sedangkan pada sistem tugal sebesar 6,93 HKO dengan persentase $11,35 \%$. Pada kegiatan pengairan kesempatan kerja pada sistem sebar sebesar 6,64 $\mathrm{HKO}$ dan pada sistem tugal sebesar 8,49 HKO dengan persentase masing-masing $12,41 \%$ dan $13,90 \%$. Selanjutnya kesempatan kerja pada kegiatan pemanenan pada sistem sebar dan tugal masing-masing sebesar 12,82 HKO dan 10,92 HKO, dengan persentase masing-masing sebesar 23,98\% dan 17,89\%. Pada 
kegiatan perontokan kesempatan kerja pada sistem sebar dan tugal masing-masing sebesar 7,60 HKO dan 8,52 HKO dengan persentase sebesar 14,21\% dan 13,93\%.

Berdasarkan uraian diatas diketahui bahwa kesempatan kerja usahatani sistem tugal lebih besar di bandingkan sistem sebar. Perbedaan yang paling terlihat terjadi pada kesempatan kerja pada kegiatan penanaman. Hal ini disebabkan karena proses penanaman pada sistem tugal membutuhkan waktu dan tenaga yang lebih banyak karena terlebih dahulu membuat lubang tanam sebelum penanaman, selain itu juga benih yang telah ditanam ditimbun kembali dengan tanah.

\section{Analisis Komparatif Biaya Produksi, Produksi, Pendapatan dan Kesempatan Kerja Usahatani Kedelai Dengan Sistem Sebar dan Tugal}

Uji perbandingan produksi, biaya produksi, pendapatan, dan kesempatan kerja di lakukan menggunakan uji-t. hasil perbandingan dapat dilihat pada Tabel 3.

Tabel 3. Biaya Produksi, Produksi, Pendapatan, dan Kesempatan Kerja Usahatani Kedelai dengan Sistem Sebar dan Tugal di Kecamatan Alas Kabupaten Sumbawa 2018

\begin{tabular}{|c|l|r|r|r|r|c|}
\hline No & Perbandingan & Sistem Sebar & Sitem Tugal & $\begin{array}{l}\text { Nilai } \\
\text { t-hit. }\end{array}$ & $\begin{array}{l}\text { Nilai } \\
\text { t-tab. }\end{array}$ & Ket. \\
\hline 1 & Biaya Produksi (Rp) & $5.741 .323,84$ & $7.205 .808,64$ & 3,53 & 2,18 & S \\
\hline 2 & Produksi (Kg) & 1301,42 & 1787,04 & 4,32 & 2,18 & S \\
\hline 3 & Pendapatan (Rp) & $1.806 .935,65$ & $3.159 .007,17$ & 2,14 & 2,06 & S \\
\hline 4 & $\begin{array}{l}\text { Kesempatan } \\
\text { Kerja (HKO) }\end{array}$ & 53,47 & 61,06 & 1,35 & 2,16 & NS \\
\hline
\end{tabular}

Sumber : Data primer diolah

Biaya produksi. Tabel 3 menunjukkan bahwa biaya produksi usahatani sistem sebar lebih kecil dibandingkan sistem tugal. Setelah diuji dengan t-test pada taraf nyata $5 \%$ diperoleh nilai t-hit $=3,53>\mathrm{t}$-tab $=2,18$ (berbeda nyata). Hal ini berarti $\mathrm{H} 1$ diterima, yang artinya biaya produksi usahatani kedelai sistem sebar lebih kecil dibandingkan usahatani kedelai sistem tugal (Ho ditolak).

Produksi. Pada Tabel 3, tampak bahwa produksi usahatani kedelai sistem sebar lebih kecil dibandingkan sistem tugal. Setelah diuji dengan t-test pada taraf nyata 5\% diperoleh nilai t-hit $=4,32>\mathrm{t}$-tab $=2,18$ (berbeda nyata) atau Ho ditolak, artinya produksi usahatani kedelai sistem sebar lebih kecil dibandingkan usahatani kedelai sistem tugal (H1 diterima).

Pendapatan. Tampak pada Tabel 3, pendapatan pada usahatani kedelai sistem sebar dan tugal masing-masing Rp 1.806.935,65/ha dan Rp 3.159.007,17/ha. Setelah diuji dengan t-test pada taraf nyata $5 \%$ diperoleh nilai t-hit $=2,14>\mathrm{t}$-tab $=2,06$ (berbeda nyata) atau H1 diterima, artinya pendapatan usahatani kedelai sistem sebar lebih kecil dibandingkan usahatani kedelai sistem tugal (Ho ditolak).

Kesempatan kerja. Pada Tabel 3, tampak bahwa kesempatan kerja pada usahatani kedelai sistem sebar dan tugal masing-masing sebesar 53,47 HKO/ha dan $61,06 \mathrm{HKO} / \mathrm{ha}$. Setelah diuji dengan t-test pada taraf nyata $5 \%$ diperoleh nilai $\mathrm{t}$-hit $=$ 1,35> t-tab $=2,16$ (Tidak Berbeda Nyata) atau Ho diterima, artinya kesempatan kerja usahatani kedelai sistem sebar dan usahatani kedelai sistem tugal sama (H1 ditolak). 


\section{KESIMPULAN DAN SARAN}

\section{Kesimpulan}

1. Biaya produksi pada usahatani kedelai sistem sebar lebih kecil disbandingkan usahatani kedelai sistem tugal dengan nilai masing-masing secara berurutan sebesar Rp 5.741.323,84/ha dan Rp 7.205.808,64/ha, dengan persentase biaya variabel masing-masing sebesar $97,47 \%$ dan $97,68 \%$ dan sisanya $2,53 \%$ dan 2,32\% pada biaya tetap.

2. Produksi pada usahatani kedelai sistem sebar lebih kecil dibandingkan usahatani kedelai sistem tugal setelah diuji dengan uji-t dengan taraf nyata 5\% dengan nilai masing-masing secara berurutan sebesar $1.301,42 \mathrm{~kg} / \mathrm{ha}$ sebesar $1.787,04 \mathrm{~kg} / \mathrm{ha}$.

3. Pendapatan pada usahatani kedelai sistem sebar lebih kecil dibandingkan usahatani kedelai sistem tugal dengan nilai masing-masing secara berurutan sebesar Rp 1.806.935,65/ha sebesar Rp 3.159.007,17/ha.

4. Kesempatan kerja pada usahatani kedelai sistem sebar dan sitem tugal sama dengan nilai masing-masing secara berurutan sebesar 53,47 HKO/ha dan 61,06 $\mathrm{HKO} / \mathrm{ha}$, dengan kesempatan kerja paling banyak berda pada jenis kegiatan penanaman dan pemanenan yang masing-masing sebesar 8,71 $\mathrm{HKO} /$ ha dan 12,82 $\mathrm{HKO} /$ ha pada sistem sebar sedangkan 12,59 HKO/ha dan 12,82 $\mathrm{HKO} / \mathrm{ha}$ pada sistem tugal.

\section{Saran}

1. Disarankan kepada pemerintah yntuk melakukan penyuluhan kepada petani untuk menggunakan sistem tanam tugal dalam usahatani kedelai.

2. Disarankan kepada petani untuk mengoptimalkan penggunaan input seperti pupuk sesuai dengan yang direkomendasikan.

3. Disarankan kepada petani untuk menggunakan teknologi pemupukan menggunakan sistem pembenaman di antara baris tanam.

\section{DAFTAR PUSTAKA}

Amang, Bedu. 1998. Ekonomi Kedelai di Indonesia. IPB Press : Jakarta.

Rukmana, Rahmat dan Yuniarsih Yuyun. 1996.Kedelai. Kansius. Jakarta.

Nasir, Moh. 2011. Metode Penelitian. Ghalia Indonesia. Bogor.

Surakhmad, Winarto.1994. Pengantar Penelitian Ilmiah. Bandung: Tarsito.

Narbuko, Cholid dan Abu Achmadi, 2007. Metodologi Penelitian. Cetakan 8. Jakarta. 